\title{
FAKTOR-FAKTOR YANG MEMPENGARUHI MOTIVASI BELAJAR MAHASISWA PROGRAM STUDI PGSD FKIP UNIVERSITAS AHMAD DAHLAN
}

\author{
Nurhidayah \\ Dosen PGSD Universitas Ahmad Dahlan Yogyakarta
}

\begin{abstract}
Abstrak
Program Studi PGSD di FKIP UAD termasuk Prodi baru di Universitas Ahmad Dahlan. Meskipun terbilang baru berdiri, namun animo mahasiswa untuk memasuki Prodi ini sangat besar. Pada tahun pertama membuka dua 3 kelas dan pada tahun ke dua meningkat menjadi enam kelas. Animo memasuki Prodi PGSD ini menarik untuk dilakukan penelitian tentang faktor-faktor yang mendasari motivasi belajar mahasiswa di PGSD UAD. Penelitian ini bertujuan untuk mengetahui faktorfaktor yang mempengaruhi motivasi belajar mahasiswa FKIP UAD di Program Studi PGSD. Secara khusus tujuan yang ingin dicapai dalam penelitian ini adalah untuk mengetahui pengaruh minat, dukungan orang tua, peluang kerja terhadap motivasi belajar mahasiswa PGSD UAD. Penelitian ini termasuk jenis penelitian survey dengan subjek penelitian berjumlah 100 mahasiswa PGSD angkatan pertama. Variabel dalam penelitian ini ada tiga variabel bebas (minat, dukungan orang tua, peluang kerja) dan satu variabel terikat (motivasi belajar). Teknik pengumpulan data menggunakan questionary dengan instrumen berupa angket tertutup berskala likert. Analisis data yang digunakan dengan analisis statistikdiskriptif dan analisis regresi ganda. Hasil penelitian menunjukkan bahwa terdapat pengaruh antara minat dengan motivasi belajar mahasiswa PGSD tahun 2011/2012 dengan nilai t hitung 4,554 dan terdapat pengaruh antara dukungan orang tua dengan motivasi belajar mahasiswa PGSD tahun 2011/2012 dengan nilai t hitung 4,551. Hal ini juga mengindikasikan bahwa semakin tinggi minat dan dukungan orang tua maka motivasi belajar yang dimiliki juga semakin tinggi. Sedangkan untuk variabel peluang kerja tidak menunjukkan pengaruh terhadap motivasi belajar mahasiswa PGSD tahun 2011/2012 dengan nilai $\mathrm{t}$ hitung 1,446 . Hal ini mengindikasikan bahwa peluang kerja tidak menjadi bagian yang dapat memotivasi belajar para mahasiswa.
\end{abstract}

Kata-Kata Kunci : Minat, Dukungan Orang Tua, Peluang Kerja, dan Motivasi Belajar Mahasiswa PGSD UAD

\begin{abstract}
Program PGSD UAD including new Prodi in Ahmad Dahlan University. Although relatively new to stand, but the interest of students to enter this program is huge. In the first open class two and three in the second year increased to six classes. Animo to enter PGSD Prodi's excites to do research on the factors underlying
\end{abstract}


students' learning motivation in PGSD UAD. This study aims to determine the factors that affect student learning motivation in the UAD Guidance and Counseling Program PGSD. Specifically the objectives of this study were to determine the effect of interest, parental support, employment opportunities to the students' learning motivation PGSD UAD. This research includes survey with research subjects totaling 100 students of the first batch PGSD. The variables in this study there are three independent variables (interest, parental support, employment opportunities) and one dependent variable (motivation to learn). Questionary data collection techniques using the enclosed questionnaire instrument Likert scale. Analysis of the data used by statistikdiskriptif analysis and multiple regression analysis. The results showed that there are significant between student interest and motivation to learn PGSD year 2011/2012 with a value of 4,554 $\mathrm{t}$ and there is influence between parental support and motivation to learn PGSD students in 2011/2012 with t value 4.551. It also indicates that the higher interest and support parents owned the motivation to learn also higher. As for the employment variable does not show the effect on student learning motivation PGSD year 2011/2012 with $t$ value 1.446. This indicates that the employment opportunities that can not be part of learning to motivate students.

Keywords: Interests, Parent Support, Job Opportunities, and Learning Motivation of Students PGSD UAD.

\section{A. Pendahuluan}

Pendidikan merupakan alat yang menentukan untuk mencapai kemajuan dalam segala bidang penghidupan, dalam memilih dan membina hidup yang baik, yang sesuai dengan martabat manusia. Pendidikan akan terasa gersang apabila tidak berhasil mencetak Sumber Daya Manusia (SDM) yang berkualitas (baik dari segi spiritual, intelegensi, dan skill). Untuk itu, perlu diusahakan peningkatan mutu pendidikan, supaya bangsa kita tidak terus bertahan pada status bangsa yang sedang berkembang tetapi bisa menyandang predikat bangsa maju dan tidak kalah bersaing dengan bangsa lain.

Dalam Undang-Undang No 20 tahun 2003 disebutkan bahwa pendidikan adalah usaha sadar dan terencana untuk mewujudkan suasana belajar dan proses pembelajaran agar peserta didik secara aktif mengembangkan potensi dirinya untuk memiliki kekuatan spiritual keagamaan, pengendalian diri, kepribadian, kecerdasan, 
akhlak mulia, serta ketrampilan yang diperlukan dirinya, masyarakat, bangsa, dan negara.

Berdasarkan definisi tersebut di atas diketahui bahwa orientasi pendidikan adalah untuk mendewasakan dan mematangkan peserta didik, sehingga akan menjadi sosok pribadi yang memiliki kemandirian dalam menghadapi berbagai persoalan baik yang muncul selama mengikuti proses pendidikan maupun yang terdapat dalam kehidupan sehari-hari.

Menurut Suryabrata (1984: 14) bahwa salah satu factor yang mempengaruhi hasil belajar adalah factor dari dalam diri seseorang yang meliputi keadaan fisiologis dan psikologis, factor fisiologis meliputi keadaan fisik seseorang secara umum, kondisi panca indra, sedangkan factor psikologis meliputi minat, bakat, motivasi dan kemampuan kognitif. Hal ini berarti berarti bahwa prestasi belajar yang rendah dapat disebabkan oleh motivasi belajar yang rendah. Keberhasilan peserta didik (mahasiswa) dalam aktivitas pendidikan tidak akan lepas dari dorongan (motivasi) yang ditanamkan pada mahasiswa tersebut. Motivasi adalah sebagai suatu daya (dorongan) pada seseorang yang menyebabkan seseorang melakukan perbuatan tertentu (Sardiman, 2010: 73).

Shalahudin, M (1990: 57) menyebutkan bahwa motivasi belajar seseorang dipengaruhi oleh dua faktor yaitu faktor ekstrinsik meliputi lingkungan (alam dan sosial), perhatian orang tua, kurikulum, pengajar, sarana prasarana, fasilitas, dan administrasi, sedang faktor yang kedua yaitu faktor intrinsik yang meliputi fisiologis (kondisi fisik) dan psikologi (sikap, bakat, minat, kecerdasan, dan kemampuan koqnitif).

Lebih jelas Purwanto (1984:107) menekankan bahwa faktor ekstrinsik yang mempengaruhi motivasi belajar seorang mahasiswa dipengaruhi oleh dua hal yaitu lingkungan alam dan lingkungan sosial (masyarakat dan keluarga). Untuk menciptakan lingkungan keluarga yang dapat memotivasi mahasiswa dalam belajar secara optimal maka erat kaitannya dengan peran serta orang tua. Perhatian orang tua 
dalam memotivasi belajar anaknya merupakan faktor yang penting dalam suksesnya belajar.

Ada beberapa mahasiswa yang masuk di program studi PGSd mempunyai intake /kemampuan awal yang pas-pasan atau bahkan berkemampuan rendah, ada juga mahasiswa yang berasal dari SMK. Bahkan mereka masuk di program studi PGSD ada yang karena tidak diterima di universitas/jurusan yang lain. Dengan adanya motivasi belajar yang positif diharapkan akan menumbuhkan prestasi belajar mahasiswa yang lebih baik. Dimana motivasi belajar mahasiswa perlu diketahui oleh dosen di program studi, sehingga dosen dapat mengarahkan mahasiswa untuk melakukan pilihan dalam menentukan cita-citanya.

Banyak dijumpai orang tua yang kurang memperhatikan pendidikan putraputrinya, mereka sibuk dengan urusan dan pekerjaan masing-masing, mereka lupa menyisihkan waktu untuk sekedar menyapa putra-putrinya, mengontrol kegiatan putra-putrinya,mereka juga lupa membantu putra-putrinya dalam menyelesaikan permasalahan yang dihadapi. Kebanyakan orang tua ingin sekali agar anaknya mencapai prestasi yang tinggi, mereka ingin membantu perkembangan intelektual dan social mereka secara tulus dan ikhlas, tetapi orang tua mempunyai kesukaran untuk mewujudkan keinginannya itu menjadi perbuatan yang efektif. Keinginan yang kuat dari orang tua agar anaknya berhasil, tetapi orang tua tidak banyak berbuat sesuatu yang efektif dalam mendorong putra-putrinya untuk belajar.

Orang tua yang baik adalah yang mendorong aktifitas belajar bagi anakanaknya, juga orang tua yang bisa menerima anak sebagaimana adanya, lembut namun menetapkan batas-batas yang fleksibel dalam mengatur tingkah laku anakanaknya, orang tua memberikan kesempatan dan perlengkapan belajar bagi anakanaknya, orang tua menunjukkan harapan yang positif, orang tua memberi nasehat dan menjadi contoh yang baik, orang tua memberikan penguatan atau penghargaan terhadap tingkah laku dan usaha belajar yang baik. Sikap orang tua yang seperti ini dapat mendorong belajar anak-anaknya. 
Seorang mahasiswa yang baik mestinya dia akan selalu hadir mengikuti perkuliahan dengan rajin, tidak suka membolos, belajar dengan giat, tekun dan penuh semangat, memperhatikan dengan sungguh-sungguh dalam pembelajaran, mengerjakan tugas dengan baik, mempunyai sikap dan kepribadian yang baik. Mereka mempunyai cita-cita dan harapan yang dapat mendorong untuk belajar dengan giat dan tekun, dan memiliki kemampuan memadukan pengetahuan yang dimiliki untuk menyongsong hari esok yang lebih baik.

Sarana belajar adalah segala sesuatu yang dipergunakan pendidik dalam usahanya untuk mencapai tujuan pendidikan yang telah dirumuskan. Sarana belajar meliputi hal-hal berikut: ruangan, peralatan dan media untuk belajar. Dewasa ini semakin dirasakan betapa pentingnya peranan sarana belajar dalam mendukung tercapainya tujuan pendidikan yang diharapkan. Sarana belajar dipandang dapat membantu kearah keberhasilan kegiatan komunikasi untuk mentransfer pengetahuan dan untuk mengembangkan kemampuan anak didik. Sarana belajar yang tersedia dirumah maupun disekolah ikut berperan dalam meningkatkan keinginan peserta didik dalam interaksi pembelajaran.

Berdasarkan hal tersebut di atas maka peneliti tertarik untuk meneliti faktorfaktor yang berpengaruh terhadap motivasi belajar mahasiswa PGSD UNiversitas Ahmad Dahlan. Harapan kedepan jika motivasi belajar mahasiswa dapat terpupuk dengan baik maka prestasi belajarnyapun juga meningkat sehingga mampu memberikan andil dalam peningkatan mutu pendidikan.

\section{B. Metode Penelitian}

Penelitian yang akan dilakukan masuk dalam kelompok penelitian expost facto. Penelitian ex-post facto menurut Suryabrata (2010: 85) adalah penelitian dimana variabel yang hendak diteliti (variabel terikat) telah ada pada saat penelitian dilakukan, atau dengan kata lain yaitu penelitian untuk meneliti peristiwa yang telah terjadi dan tidak memberikan perlakuan terhadap variabel yang diteliti. Peneliti tidak dapat memanipulasi keadaan karena faktanya telah terjadi. Data dikumpulkan setelah 
semua kejadian yang dipersoalkan sudah lewat untuk menjelaskan akibat pada saat ini. Pada penelitian ex-post facto keterikatan antara variabel bebas (independent variable) dengan variabel terikat (dependent variable) sudah terjadi secara alami, dengan setting tersebut ingin menelusuri kembali apa yang menjadi faktor penyebabnya.

Jenis penelitian yang mempelajari suatu keadaan atau status suatu fenomena, adalah penelitian deskriptif kuantitatif, Jenis penelitian ini dipilih karena sejak proses pengumpulan data, pengoilahan (analisis) data, hingga penyajiannya semua data dalam bentuk angka

\section{Pembahasan dan Kesimpulan}

Penelitian ini terdiri dari dua variabel penelitian yaitu variabel bebas dan variable terikat, kedua variable tersebut dibagi dalam tiga variable bebas terdiri atas minat belajar $\left(\mathrm{X}_{1}\right)$, dukungan orang tua $\left(\mathrm{X}_{2}\right)$, peluang kerja $\left(\mathrm{X}_{3}\right)$, sedangkan variable terikat berupa motivasi belajar (Y).

Data hasil penelitian dari masing-masing variabel dapat dideskripsikan dengan skor tertinggi, skor terendah, rata-rata, dan standar deviasi, yang selanjutnya hasilnya dikonversikan untuk menentukan kreteria dari masing-masing variabel dengan menggunakan acuan sebagai berikut.

Tabel 1. Kriteria skor variable $\mathrm{X}_{1}, \mathrm{X}_{2}, \mathrm{X}_{3}$, dan $\mathrm{Y}$

\begin{tabular}{|l|l|}
\hline Skor & Kriteria \\
\hline $\mathrm{X} \geq(\mathrm{M}+1,50 . \mathrm{SD})$ & Sangat tinggi \\
$(\mathrm{M}+0,50 . \mathrm{SD}) \leq \mathrm{X}<(\mathrm{M}+1,50 . \mathrm{SD})$ & Tinggi \\
$(\mathrm{M}-0,50 . \mathrm{SD}) \leq \mathrm{X}<(\mathrm{M}+0,50 . \mathrm{SD})$ & Sedang \\
$(\mathrm{M}-0,50 . \mathrm{SD}) \leq \mathrm{X}<(\mathrm{M}-1,50 . \mathrm{SD})$ & Rendah \\
$\mathrm{X}<(\mathrm{M}-1,50 . \mathrm{SD})$ & Sangat rendah \\
\hline
\end{tabular}

Sumber : Sutrisno, H (2000:45) 


$$
\begin{aligned}
\text { Keterangan }: & M=\text { rata-rata nilai } \\
& X=\text { nilai skor } \\
& S D=\text { standar deviasi }
\end{aligned}
$$

\section{Variabel Minat Belajar Mahasiswa (X1)}

Berdasarkan data minat belajar $\left(X_{1}\right)$ yang dapat dilihat pada lampiran 6 memiliki rentang skor antara 10 sampai 40, skor rata-rata 25 dan standar deviasi 5. Berdasarkan hasil skor dari variable minat maka dapat dihitung kreteria skor dari variabel minat belajar mahasiswa di PGSD sebagai berikut.

Tabel 2. Kriteria Skor Variable Minat Belajar

\begin{tabular}{|l|l|}
\hline Skor & Kriteria \\
\hline $\mathrm{X} \geq 32,5$ & Sangat tinggi \\
$27,5<\mathrm{X} 1 \leq 32,5$ & Tinggi \\
$22,5<\mathrm{X} 1 \leq 27,5$ & Sedang \\
$22,5<\mathrm{X} 1 \leq 17,5$ & Rendah \\
$\mathrm{X}<17,5$ & Sangat rendah \\
\hline
\end{tabular}

Berdasarkan tabel kriteria skor minat belajar di PGSD UAD di atas terdapat lima kriteria yaitu sangat tinggi berada pada skor $X \geq 32,5$, kriteria tinggi berada pada skor $27,5<\mathrm{X} 1 \leq 32,5$, kriteria sedang berada pada skor $22,5<\mathrm{X} 1 \leq 27,5$, criteria rendah berada pada skor $22,5<\mathrm{X} 1 \leq 17,5$, dan sangat rendah berada pada skor $\mathrm{X}<17,5$. Distribusi frekuensi dan persentase minat belajar mahasiswa dapat dilihat pada tabel berikut.

Tabel 3. Distribusi Frekuensi Skor Nilai Minat Belajar Mahasiswa PGSD

\begin{tabular}{|l|l|l|l|}
\hline Kategori & Rentang Skor & Frekuensi & Persentase \\
\hline
\end{tabular}




\begin{tabular}{|c|c|c|c|}
\hline Sangat tinggi & $32,5-40,00$ & 51 & 0,51 \\
\hline Tinggi & $27,5-32,5$ & 46 & 0,46 \\
\hline Sedang & $22,5-27,5$ & 3 & 0,03 \\
\hline \multicolumn{2}{|c|}{ Total } & 100 & 100 \\
\hline
\end{tabular}

Berdasarkan pada tabel di atas dapat diketahui $51 \%$ atau 51 mahasiswa PGSD UAD memiliki minat belajar pada kategori sangat tinggi; $46 \%$ atau 46 mahasiswa dengan kategori tinggi dan 3\% atau 3 mahasiswa dalam kategori sedang kategori rendah dan sangat rendah tidak ada. Hal ini menunjukkan bahwa minat belajar mahasiswa PGSD UAD termasuk dalam kategori sangat tinggi yang ditunjukkan oleh persentasi terbesar skor tersebut.

\section{Variabel dukungan orang tua (X2)}

Berdasarkan data dukungan orang tua $\left(\mathrm{X}_{2}\right)$ yang dapat dilihat pada lampiran 6 memiliki rentang skor antara 15 sampai 60, skor rata-rata 37,5 dan standar deviasi 7,5. Berdasarkan hasil skor dari variabel dukungan orang tua dapat dibagi menjadi lima kriteria yaitu sangat tinggi, tinggi, sedang, rendah, dan sangat rendah. Dibawah ini adalah tabel kriteria untuk skor dukungan orang tua.

Tabel 4. Kriteria Skor Variable Dukungan Orang Tua

\begin{tabular}{|l|l|}
\hline Skor & Kriteria \\
\hline $\mathrm{X} 2 \geq 48,5$ & Sangat tinggi \\
$41,25<\mathrm{X} 2 \leq 48,75$ & Tinggi \\
$33,75<\mathrm{X} 2 \leq 41,25$ & Sedang \\
$26,25<\mathrm{X} 2 \leq 33,75$ & Rendah \\
\hline
\end{tabular}


Berdasarkan tabel kriteria dukungan orang tua di atas terdapat lima kriteria yaitu sangat tinggi berada pada skor $X \geq 48,5$, kriteria tinggi berada pada skor $41,25<\mathrm{X} 1 \leq 48,75$, kriteria sedang berada pada skor $33,75<\mathrm{X} 1 \leq 41,25$, kriteria rendah berada pada skor $26,5<X 1 \leq 33,75$, dan sangat rendah berada pada skor $X<26,25$. Distribusi frekuensi dan persentase dukungan orang tua dapat dilihat pada table 7 .

Tabel 5. Distribusi Frekuensi Skor Nilai Dukungan Orang Tua

\begin{tabular}{|c|l|c|c|}
\hline Kategori & \multicolumn{1}{|c|}{ Rentang Skor } & Frekuensi & Persentase \\
\hline Sangat tinggi & $48,5-60$ & 60 & 0,60 \\
\hline Tinggi & $41,25-48,5$ & 33 & 0,33 \\
\hline Sedang & $33,75-41,25$ & 7 & 0,07 \\
\hline \multicolumn{2}{|c|}{ Total } & 100 & 100 \\
\hline
\end{tabular}

Berdasarkan pada tabel di atas dapat diketahui $60 \%$ atau 60 siswa PGSD UAD memiliki dukungan dari orang tua pada kategori sangat tinggi; $33 \%$ atau 33 mahasiswa dalam kategori tinggi dan 7\% atau 7 mahasiswa dalam kategori sedang, sedangkan kategori rendah dan sangat rendah tidak ada. Hal ini menunjukkan bahwa orang tua memberikan dukungan sepenuhnya terhadap putra-putrinya yang melanjutkan studi di PGSD UAD.

\section{Variabel Peluang Kerja (X3)}

Berdasarkan data peluang kerja $\left(\mathrm{X}_{3}\right)$ yang dapat dilihat pada lampiran 6 memiliki rentang skor antara 10 sampai 40, skor rata-rata 25 dan standar deviasi 5 . Berdasarkan hasil skor dari variable peluang kerja dapat dibagi menjadi lima criteria 
yaitu sangat tinggi, tinggi, rendah, dan sangat rendah. Dibawah ini adalah tabel kriteria untuk skor peluang kerja.

Tabel 6. Kriteria skor variable minat

\begin{tabular}{|l|l|}
\hline Skor & Kriteria \\
\hline$X \geq 32,5$ & Sangat tinggi \\
$27,5<X 3 \leq 32,5$ & Tinggi \\
$22,5<X 3 \leq 27,5$ & Sedang \\
$22,5<X 3 \leq 17,5$ & Rendah \\
$X<17,5$ & Sangat rendah \\
\hline
\end{tabular}

Berdasarkan tabel kriteria skor peluang kerja untuk lulusan PGSD UAD di atas terdapat lima kriteria yaitu sangat tinggi berada pada skor $\quad X \geq 32,5$, kriteria tinggi berada pada skor $27,5<\mathrm{X} 1 \leq 32,5$, kriteria sedang berada pada skor $22,5<\mathrm{X} 1 \leq 27,5$, kriteria rendah berada pada skor $22,5<\mathrm{X} 1 \leq 17,5$, dan sangat rendah berada pada skor $X<17,5$. Distribusi frekuensi dan persentase minat belajar mahasiswa dapat dilihat pada tabel 7.

Tabel 7. Distribusi Frekuensi Skor Peluang Kerja

\begin{tabular}{|c|c|c|c|}
\hline Kategori & Rentang Skor & Frekuensi & Persentase \\
\hline Sangat tinggi & $32,5-40,00$ & 23 & 0,23 \\
\hline Tinggi & $27,5-32,5$ & 51 & 0,51 \\
\hline Sedang & $22,5-27,5$ & 25 & 0,25 \\
\hline Rendah & $17,5-22,5$ & 1 & 0,01 \\
\hline
\end{tabular}




\begin{tabular}{|l|l|l|}
\hline Total & 100 & 100 \\
\hline
\end{tabular}

Berdasarkan pada tabel di atas dapat diketahui 23\% atau 23 siswa PGSD UAD memiliki keyakinan akan peluang kerja setelah lulus dari PGSD UAD pada kategori sangat tinggi; $51 \%$ atau 51 mahasiswa yakin peluang kerjanya dalam kategori tinggi, sedangkan yang berada dalam kategori sedang ada $25 \%$ atau 25 mahasiswa dan dalam ketegori rendah 1 mahasiswa atau 0,01\%. Hal ini menunjukkan bahwa lebih dari 50\% mahasiswa percaya bahwa peluang kerja lulusan PGSD UAD termasuk dalam kategori tinggi.

\section{Variabel Motivasi belajar (Y)}

Berdasarkan data motivasi belajar (Y) yang dapat dilihat pada lampiran 6 memiliki rentang skor antara 17 sampai 68 , skor rata-rata 42,5 dan standar deviasi 8,5. Berdasarkan hasil skor dari variabel motivasi belajar dapat dibagi menjadi lima kriteria yaitu sangat tinggi, tinggi, rendah, dan sangat rendah. Dibawah ini adalah tabel kriteria untuk skor motivasi belajar di PGSD.

Tabel 8 Kriteria Skor Variable Motivasi Belajar

\begin{tabular}{|l|l|}
\hline Skor & Kriteria \\
\hline $\mathrm{X} \geq 55,25$ & Sangat tinggi \\
$46,75<\mathrm{X} 1 \leq 55,25$ & Tinggi \\
$38,25<\mathrm{X} 1 \leq 46,75$ & Sedang \\
$29,75<\mathrm{X} 1 \leq 38,25$ & Rendah \\
$\mathrm{X}<29,5$ & Sangat rendah \\
\hline
\end{tabular}

Berdasarkan tabel kriteria skor motivasi belajar di PGSD UAD di atas terdapat lima kriteria yaitu sangat tinggi berada pada skor $X \geq 55,25$, kriteria tinggi 
berada pada skor $38,25<\mathrm{X} 1 \leq 32,5$, kriteria sedang berada pada skor $22,5<\mathrm{X} 1 \leq 27,5$, kriteria rendah berada pada skor $22,5<\mathrm{X} 1 \leq 17,5$, dan sangat rendah berada pada skor $X<17,5$. Distribusi frekuensi dan persentase motivasi belajar siswa pada tabel 9 .

Tabel 9 Distribusi Frekuensi Skor Nilai Motivasi Belajar Mahasiswa PGSD

\begin{tabular}{|c|c|c|c|}
\hline Kategori & Rentang Skor & Frekuensi & Persentase \\
\hline Sangat tinggi & $55,25-68,00$ & 35 & 0,35 \\
\hline Tinggi & $46,75-55,25$ & 61 & 0,61 \\
\hline Sedang & $38,25-46,75$ & 4 & 0,04 \\
\hline \multicolumn{2}{|c|}{ Total } & 100 & 100 \\
\hline
\end{tabular}

Berdasarkan pada tabel di atas dapat diketahui 35\% atau 35 mahasiswa PGSD UAD memiliki motivasi belajar pada kategori sangat tinggi; dalam kategori tinggi $61 \%$ atau 61 mahasiswa dalam kategori sedang $4 \%$ atau 4 mahasiswa dalam ketegori sedang. Hal ini menunjukkan bahwa motivasi belajar mahasiswa PGSD UAD termasuk dalam kategori tinggi yang ditunjukkan oleh persentasi terbesar skor tersebut.

\section{A. Analisis Regresi}

Sebelum melakukan uji regresi, terdapat persyaratan yang harus dilalui untuk melakukan uji regresi ganda, yaitu minimal harus memenuhi syarat normalitas dan linearitas.

\section{Uji normalitas}

Uji normalitas data pada penelitian ini dilakukan dengan uji One sample Kolmogorof Smirnov Test dengan signifikan $(<0,05)$ pada taraf $5 \%$, maka data 
tersebut berdistribusi tidak normal. Sebaliknya jika nilai jika nilai $\alpha$ tidak signifikan (> 0,05), maka distribusi data adalah normal. Uji normalitas dilakukan dengan menggunakan bantuan komputer seri program SPSS for windows yang disajikan pada lampiran 7. Hasil uji normalitas variabel dapat dilihat pada tabel 12 di bawah ini.

Tabel 10. Hasil Uji Normalitas Data

\begin{tabular}{|c|l|c|c|}
\hline No. & \multicolumn{1}{|c|}{ Variabel } & P value & Keterangan \\
\hline 1. & Minat Belajar $\left(\mathrm{X}_{1}\right)$ & 0,394 & Berdistribusi Normal \\
\hline 2. & Dukungan Orang Tua $\left(\mathrm{X}_{2}\right)$ & 0,080 & Berdistribusi Normal \\
\hline 3. & Peluang kerja $\left(\mathrm{X}_{3}\right)$ & 0,075 & Berdistribusi Normal \\
\hline 5. & Motivasi Belajar $(\mathrm{Y})$ & 0,220 & Berdistribusi Normal \\
\hline
\end{tabular}

Berdasarkan hasil yang terdapat pada table di atas tampak nilai untuk variabel Minat Belajar $\left(\mathrm{X}_{1}\right)$, Dukungan Orang Tua $\left(\mathrm{X}_{2}\right)$, Peluang Kerja $\left(\mathrm{X}_{3}\right)$, dan motivasi belajar (Y) masing-masing mempunyai nilai $\mathrm{p}$ sebesar 0,$394 ; 0,080 ; 0,075 ; 0,220$, yang lebih besar dari nilai $0,05(\mathrm{p}>0,05)$. Dengan demikian dapat disimpulkan bahwa data variabel Minat Belajar $\left(\mathrm{X}_{1}\right)$, Dukungan Orang Tua $\left(\mathrm{X}_{2}\right)$, Peluang Kerja $\left(\mathrm{X}_{3}\right)$, dan motivasi belajar $(\mathrm{Y})$ berdistribusi normal.

\section{Uji Linieritas}

Uji linierits hubungan dimaksudkan untuk mengetahui apakah hubungan antara variable bebas dengan variable terikat bersifat linier atau tidak, uji linieritas variable $\mathrm{X}_{1}, \mathrm{X}_{2}, \mathrm{X}_{3}$, sebagai variable bebas dengan variable $\mathrm{Y}$ sebagai variable terikat. Adapun pengujian linieritas hubungan pada penelitian ini dengan menggunakan analisis sederhana. Perhitungannya dilakukan dengan program SPSS 15.00 for windows dengan hasil seperti yang tercantum dalam lampiran 8. Pedoman yang digunakan untuk menguji linieritas dilakukan dengan jalan menguji signifikansi nilai $\mathrm{F}$. 
Untuk variable minat belajar $\left(\mathrm{X}_{1}\right)$ diperoleh koefisien korelasi sebesar 0,684; persamaan garis regresi $\mathrm{Y}=5,600 \mathrm{X}_{1}+73,035$ dan didapatkan $\mathrm{F}$ regresi sebesar 0,783 dan $p=0,000$ dimana menunjukkan signifikansi pada taraf signifikansi 0,05 sehingga dapat disimpulkan bahwa hubungan antara kedua variable itu secara signifikan adalah linier.

Untuk variable dukungan orang tua $\left(\mathrm{X}_{2}\right)$ diperoleh koefisien korelasi sebesar 0,058 persamaan garis regresi $\mathrm{Y}=6,965 \mathrm{X}_{2}+79,816$ dan didapatkan $\mathrm{F}$ regresi sebesar 1,762 dan $\mathrm{p}=0,000$ dimana menunjukkan signifikansi pada taraf signifikansi 0,05 sehingga dapat disimpulkan bahwa hubungan antara kedua variable itu secara signifikan adalah linier.

Untuk variable peluang kerja $\left(\mathrm{X}_{3}\right)$ diperoleh koefisien korelasi sebesar 0,059; persamaan garis regresi $\mathrm{Y}=3,560 \mathrm{X}_{1}+26,645$ dan didapatkan $\mathrm{F}$ regresi sebesar 0,783 dan $\mathrm{p}=0,000$ dimana menunjukkan signifikansi pada taraf signifikansi 0,05 sehingga dapat disimpulkan bahwa hubungan antara kedua variable itu secara signifikan adalah linier.

Adapun rangkuman hasil uji linieritas hubungan dapat dilihat pada tabel 13 berikut, sedangkan perhitungan selengkapnya dapat dilihat pada lampiran 9 .

Tabel 11. Rangkuman Hasil Uji Linieritas Hubungan

\begin{tabular}{|l|l|l|l|l|}
\hline No & $\begin{array}{l}\text { Pasangan } \\
\text { Variabel }\end{array}$ & $\begin{array}{l}\text { Koefisien } \\
\text { Korelasi }\end{array}$ & F Regresi & Keterangan \\
\hline 1 & $\mathrm{X} 1 \rightarrow \mathrm{Y}$ & 0,684 & 0,837 & Linier \\
2 & $\mathrm{X} 2 \rightarrow \mathrm{Y}$ & 0,058 & 1,762 & Linier \\
3 & $\mathrm{X} 3 \rightarrow \mathrm{Y}$ & 0,059 & 1,784 & Linier \\
\hline
\end{tabular}

Berdasarkan hasil analisis uji linieritas hubungan pada tabel 13 tersebut di atas menunjukkan bahwa hubungan antara variable bebas, yaitu : minat belajar (X1), 
dukungan orang tua (X2), peluang kerja (X3) dan motivasi kerja (Y) masing-masing signifikan. Hal ini berarti koefisien arah regresinya linier, dan dengan demikian syarat linier terpenuhi.

\section{Uji Hipotesis}

Pengujian hipotesis dalam penelitian ini menggunakan analisis regresi sebagaimana digambarkan dalam bab III yang diestimasi dengan suatu persamaan regresi yaitu memprediksi motivasi belajar terhadap beberapa factor yang mempengaruhinya. Karena dalam penelitian ini terdiri dari tiga variabel bebas dan satu variable terikat, maka pengujian hipotesis dilakukan dengan beberapa teknik analisis statistic yaitu analisis regresi berganda dan analisis korelasi parsial.

Hipotesis yang diajukan dalam penelitian ini berbunyi : "Minat, dukungan orang tua, dan peluang kerja secara bersama-sama memiliki pengaruh yang signifikan terhadap motivasi belajar mahasiswa PGSD UAD. Untuk menguji hipotesis tersebut dilakukan dengan menggunakan analisis regresi ganda dengan 3 prediktor.

Adapun rangkuman hasil analisis besarnya sumbangan masing-masing variable dapat dilihat pada tabel dibawah ini dan perhitungan selengkapnya ada dilampiran 9.

Tabel 11. Rangkuman Analisis Regresi Ganda

\begin{tabular}{|c|c|c|c|c|c|c|c|}
\hline \multirow[t]{3}{*}{ Model } & \multicolumn{2}{|c|}{$\begin{array}{r}\text { Understandardi } \\
\text { zed Coeficient }\end{array}$} & $\begin{array}{l}\text { Stand } \\
\text { ardize }\end{array}$ & \multirow[t]{3}{*}{$\mathbf{t}$} & \multirow[t]{3}{*}{ Sig. } & \multirow{2}{*}{\multicolumn{2}{|c|}{$\begin{array}{r}\text { Colinearity } \\
\text { Statistic }\end{array}$}} \\
\hline & & & $\begin{array}{l}\text { Coeffi } \\
\text { cients }\end{array}$ & & & & \\
\hline & B & $\begin{array}{r}\text { Std. } \\
\text { Erro }\end{array}$ & Beta & & & $\begin{array}{r}\text { Toleran } \\
\text { ce }\end{array}$ & VIF \\
\hline
\end{tabular}




\begin{tabular}{|r|r|r|r|r|r|r|r|}
\hline & & $\mathbf{r}$ & & & & & \\
\hline (Constant) & 9.522 & 4.197 & & 2.269 & .026 & & \\
$\left(\mathrm{X}_{1}\right)$ & .558 & .123 & .392 & 4.554 & .000 & .623 & 1.606 \\
$\left(\mathrm{X}_{2}\right)$ & .443 & .097 & .383 & 4.551 & .000 & .651 & 1.537 \\
$\left(\mathrm{X}_{3}\right)$ & .164 & .112 & .114 & 1.466 & .146 & .765 & 1.307 \\
& & & & & & & \\
\hline
\end{tabular}

Hasil analisis regresi menunjukkan bahwa diantara 3 variabel bebas yang ada variabel minat (X1) merupakan variable yang paling dominan memberikan pengaruh terhadap motivasi belajar mahasiswa (Y) sebesar $\beta 0,558$ dengan $\mathrm{t}=4,554$ dan $\mathrm{p}=$ 0,000 . Kemudian diikuti oleh variable dukungan orang tua sebesar $\beta=0,443$ dengan $\mathrm{t}$ $=4,551$ dan $\mathrm{p}=0,000$. Sedangkan untuk variable peluang Kerja $\left(\mathrm{X}_{3}\right)$ sebesar $\beta=$ 0,164 dengan $\mathrm{t}=1,466$ dan $\mathrm{p}=0,146$,.dimana pengaruhnya tidak signifikan karena nilai $\mathrm{p}$ tersebut jauh lebih besar dari taraf nyata 0,05 .

\section{a. Pengujian Hipotesis Pertama}

Hipotesis pertama yang pertama berbunyi : Ada pengaruh yang signifikan antara minat terhadap motivasi belajar mahasiswa PGSD UAD, untuk menguji hipotesis pertama dengan menggunakan teknik analisis sederhana dengan menggunakan uji t. Kriteria keputusan adalah jika $t$ hitung $>t$ tabel, maka hipotesis diterima. Hal ini mengandung pengertian bahwa minat berpengaruh terhadap motivasi belajar mahasiswa PGSD.

Hasil perhitungan diperoleh harga koefisien regresi sebesar 0,558, positif berarti semakin tinggi minat maka semakin tinggi motivasi belajar, semakin rendah minat maka semakin rendah motivasi belajar. Setelah dikonsultasikan dengan $r$ tabel pada $\mathrm{n}=100$ diperoleh nilai $\mathrm{r}$ tabel 1,6604. Analisis regresi linier sederhana diperoleh $\mathrm{t}$ hitung 4,554 pada taraf signifikan $5 \%$. Karena $\mathrm{t}_{\text {hitung }}>\mathrm{t}_{\text {tabel }}(4,554>1,6604)$ maka 
hipotesis pertama diterima yaitu ada pengaruh antara minat terhadap motivasi belajar mahasiswa PGSD.

\section{b. Pengujian Hipotesis kedua}

Hipotesis kedua yang pertama berbunyi : Ada pengaruh yang signifikan antara dukungan dari orang tua terhadap motivasi belajar mahasiswa PGSD UAD, untuk menguji hipotesis kedua dengan menggunakan teknik analisis sederhana dengan menggunakan uji t. Kriteria keputusan adalah jika $t_{\text {hitung }}>\mathrm{t}_{\text {tabel }}$, maka hipotesis diterima. Hal ini mengandung pengertian dukungan dari orang tua berpengaruh terhadap motivasi belajar mahasiswa PGSD.

Hasil perhitungan diperoleh harga koefisien regresi sebesar 0,443, positif berarti semakin tinggi dukungan orang tua maka semakin tinggi motivasi belajar, semakin rendah dukungan orang tua maka semakin rendah motivasi belajar. Setelah dikonsultasikan dengan $\mathrm{r}$ tabel pada $\mathrm{n}=100$ diperoleh nilai $\mathrm{r}$ tabel 1,6604. Analisis regresi linier sederhana diperoleh $t$ hitung 4,554 pada taraf signifikan $5 \%$. Karena $t$ hitung $>\mathrm{t}_{\text {tabel }}(4,551>1,6604)$ maka hipotesis kedua diterima yaitu ada pengaruh antara dukungan orang tua terhadap motivasi belajar mahasiswa PGSD.

\section{c. Pengujian Hipotesis ketiga}

Hipotesis ketiga yang pertama berbunyi : Ada pengaruh yang signifikan antara peluang kerja terhadap motivasi belajar mahasiswa PGSD UAD, untuk menguji hipotesis ketiga dengan menggunakan teknik analisis sederhana dengan menggunakan uji t. Kriteria keputusan adalah jika $t$ hitung $>t_{\text {tabel, }}$, maka hipotesis diterima. Hal ini mengandung pengertian peluang kerja berpengaruh terhadap motivasi belajar mahasiswa PGSD.

Hasil perhitungan diperoleh harga koefisien regresi sebesar 0,164 positif berarti semakin tinggi peluang kerja setelah lulus PGSD maka semakin tinggi motivasi belajar, semakin sedikit peluang kerja maka semakin rendah motivasi belajar. Setelah dikonsultasikan dengan $r$ tabel pada $n=100$ diperoleh nilai $r$ tabel 
1,6604. Analisis regresi linier sederhana diperoleh thitung 1,466 pada taraf signifikan $5 \%$. Karena $\mathrm{t}_{\text {hitung }}<\mathrm{t}_{\text {tabel }}(1,466<1,6604)$ maka hipotesis kedua ditolak yaitu tidak ada pengaruh antara peluang kerja terhadap motivasi belajar mahasiswa PGSD.

\section{Pembahasan Hasil Penelitian}

Hasil analisis dari data minat belajar menunjukkan bahwa $51 \%$ responden tergolong dalam kategori sangat tinggi, sedangkan $46 \%$ tergolong tinggi dan $3 \%$ tergolong sedang. Tingginya minat belajar tersebut ditunjukkan dengan Cita-cita, Orientasi keberhasilan, Hasrat untuk belajar.

Dalam penelitian ini signifikansi pengaruh antara minat dengan motivasi ditunjukkan dengan nilai $r$ hitung yang lebih besar dari $r$ tabel $(4,554>1,664)$. Sedangkan koefisien regresinya adalah $\mathrm{Y}=9,552+0,558 \mathrm{X}_{1}$. Dari persamaan tersebut terlihat bahwa semakin tinggi minat maka semakin tinggi motivasi belajar. Sehingga secara umum dapat terlihat bahwa mahasiswa PGSD memiliki ciri-ciri minat belajar yang tinggi sehingga akan memiliki motivasi yang tinggi pula.

Hasil analisis dari dukungan orang tua menunjukkan bahwa $60 \%$ responden tergolong dalam kategori sangat tinggi, sedangkan $33 \%$ tergolong tinggi dan $3 \%$ tergolong sedang. Tingginya dukungan orang tua tersebut ditunjukkan dengan Fasilitas yang diberikan orang tua, perhatian orang tua serta, Reward \& Punisment.

Dalam penelitian ini signifikansi pengaruh antara minat dengan motivasi ditunjukkan dengan nilai $\mathrm{r}_{\text {hitung }}>$ dari $\mathrm{r}_{\text {tabel }}(4,551>1,664)$. Sedangkan koefisien regresinya adalah $\mathrm{Y}=9,552+0,443 \mathrm{X}_{2}$. Dari persamaan tersebut terlihat bahwa semakin tinggi dukungan orang tua maka semakin tinggi motivasi belajar. Sehingga secara umum dapat terlihat bahwa mahasiswa PGSD memiliki dukungan dari orang tua yang tinggi sehingga akan memiliki motivasi yang tinggi pula.

Hasil analisis dari data peluang kerja menunjukkan bahwa $23 \%$ responden tergolong dalam kategori sangat tinggi, sedangkan 51\% tergolong tinggi, $25 \%$ 
tergolong sedang dan $1 \%$ tergolong rendah. Tingginya peluang kerja tersebut ditunjukkan dengan banyak peluang kerja, kesejahteraan, panggilan jiwa

Dalam penelitian ini peluang kerja tidak berpengaruh secara siignifikansi dengan motivasi, yang ditunjukkan dengan nilai $r$ hitung yang lebih kecil dari $r$ tabel $(1,466<1,664)$. Sedangkan koefisien regresinya adalah $\mathrm{Y}=9,552+0,164 \mathrm{X}_{3}$. Dari persamaan tersebut terlihat bahwa semakin tinggi peluang kerja maka semakin tinggi motivasi belajar.

Hasil analisis dari data motivasi belajar menunjukkan bahwa $61 \%$ responden tergolong dalam kategori tinggi, sedangkan $35 \%$ tergolong sangat tinggi dan $4 \%$ tergolong sedang. Tingginya motivasi belajar tersebut ditunjukkan dengan tekun atau ulet dalam mengerjakan tugas-tugas yang diberikan dosen, senang bekerja juga kreatif. Hal ini sesuai dengan apa yang dijelaskan oleh Sardiman (2010: ..) bahwa motivasi dapat memberikan arahan perbuatan-perbuatan yang hendak dilakukan, sehingga dalam hubungannya dengan kegiatan belajar, adanya motivasi yang baik dalam belajar akan menunjukkan belajar yang baik pula. Bahkan motivasi belajar yang baik dalam belajar merupakan pendorong pencapaian prestasi siswa (Hamalik 1992: 172).

Dalam penelitian ini persamaan koefisien regresinya adalah $\mathrm{Y}=9,552+$ $0,558 X_{1}+0,443 X_{2} .+0,164 X_{3}$. Yang berarti bahwa jika minat, dukungan orang tua dan peluang kerja maka motivasi belajar yang diperoleh seorang mahasiswa sebesar 9,552, sedangkan jika terjadi kenaikan skor minat maka motivasi belajar mahasiswa akan meningkat sebesar 0,558 dan jika terjadi kenaikan skor dukungan orang tua maka motivasi belajar mahasiswa akan meningkat sebesar 0,443 terjadi kenaikan skor peluang kerja maka motivasi belajar mahasiswa akan meningkat sebesar 0,164.

\section{KESIMPULAN}

Berdasarkan hasil penelitian, maka dapat ditarik kesimpulan sebagai berikut : 
1. Terdapat pengaruh antara minat terhadap motivasi belajar mahasiswa PGSD tahun 2011/2012 dengan nilai t hitung 4,554. Hal ini mengindikasikan semakin tinggi minat belajar yang dimiliki maka motivasi belajar yang dimiliki juga semakin tinggi.

2. Terdapat pengaruh antara dukungan orang tua terhadap motivasi belajar mahasiswa PGSD tahun 2011/2012 dengan nilai t hitung 4,551. Hal ini juga mengindikasikan bahwa semakin tinggi dukungan orang tua mahasiswa maka motivasi belajar yang dimiliki juga semakin tinggi.

3. Tidak terdapat pengaruh antar peluang kerja terhadap motivasi belajar mahasiswa PGSD tahun 2011/2012 dengan nilai t hitung 1,446. Hal mengindikasikan bahwa peluang kerja tidak menjadi bagian yang dapat memotivasi belajar para mahasiswa.

\section{DAFTAR PUSTAKA}

Barnett, Tim. 2011. Reinforcement theory. Diambil pada tanggal 11 Juni 2011, dari http://www.enotes.com/management-encyclopedia/reinforcement-theory

Chapman, $^{\text {a. } . ~ 2001 . ~ A d a m s ' ~ e q u i t y ~ t h e o r y . ~ D i a m b i l ~ p a d a ~ t a n g g a l ~} 11$ Juni 2011, dari http://www.cdrcp.com/pdf/Equity\%20Theory\%20on\%20 Job\%20Motivation.pdf

b. (2001). Maslow's hierarchy of needs. Diambil pada tanggal 11 Juni 2011, dari http://pa341.rcopper. com/files/ Abraham_Maslow_Hierarchy_of Needs.pdf

Depdiknas. 2003. Undang-Undang RI Nomor 20, tahun 2003, tentang Sistem Pendidikan Nasional

Dimyati dan Mudjiono. 2002. Belajar dan Pembelajaran. Jakarta : Rineka Cipta.

Elida Prayitno. 1989. Upaya Optimalisasi Kegiatan Belajar Mengajar. Bandung : Rosdakarya.

Hamalik, Oemar. 1992. Belajar dan Pembelajaran. Jakarta : Rineka Cipta. 
IRCO. (2007). Cross-cultural management network. Diambil pada tanggal 11 Juni 2011, dari http://www.iese.edu/es/files/IRCO-CrossCulturalmotivation_tcm5-6119.pdf

Masri Singarimbun dan Sofyan Efendi. 1989. Metode Penelitian Survai. Jakarta : LP3ES.

Ngalim Purwanto. 2010. Psikologi Pendidikan. Bandung : Rosdakarya.

Sardiman. 1996. Interaksi dan Motivasi Belajar mengajar. Jakarta : Raja Grafindo Persada

Shalahudin. Mahfudh. 1990. Pengantar Psikologi Pendidikan. Surabaya: PT Bina Ilmu

Sondang P. Siagan. 2004. Teori Motivasi dan Aplikasinya. Jakarta: PT Rineka Cipta.

Suharsimi Arikunto. 1996. Prosedur Penelitian Suatu Pendekatan Praktik. Jakarta : PT Rineka Cipta.

W.J.S Poerwodarminto 2007. Kamus Umum Bahasa Indonesia, Jakarta: Balai Pustaka

Walgito, Bimo. 1994. Psikologi Sosial. Yogyakarta : Andi Offset

\section{BIODATA PENULIS}

NAMA : NUR HIDAYAH, M.Pd

TTL : KLATEN/ 14 DES 1977 